\title{
Humor in TV Talk Shows
}

\author{
Nawal Fadhil Abbas ${ }^{1}$ \\ ${ }^{1}$ College of Education for Women, University of Baghdad, Iraq \\ Correspondence: Nawal Fadhil Abbas, College of Education for Women, University of Baghdad, Iraq. E-mail: \\ nawal_fa71@yahoo.com
}

\author{
Received: February 14, 2019 Accepted: March 19, 2019 Online Published: April 6, 2019 \\ doi:10.5539/ijel.v9n3p136 URL: https://doi.org/10.5539/ijel.v9n3p136
}

\begin{abstract}
Humor is considered a common element of human interaction. It is sometimes used to enhance the utterances so as to make them more comfortable. That is why it has been given a considerable attention by many scholars from different fields of knowledge such as linguistics, psychology and sociology. In linguistics, many scholars have tried to define humor and to show its functions and the factors that enable the humor act to be adequate and interesting. This led many theories and approaches to be formulated in order to study humor from different perspectives among which the incongruity theory by Kant (1790) and the relief theory by Moreal (1983). In addition, the non-observance of Grice's conversational maxims (1975) can also be used to create humor. Accordingly, this study aims at analyzing humor as a strategic means by which participants achieve their goals in interpersonal interaction, in particular in TV Shows, namely, Oprah Winfrey Show and Piers Morgan Show. The study also aims at investigating the way by which participants shift the topic of interaction whenever they try to avoid a certain topic by shifting to a humorous style. It is concluded that there are many factors that affect humor in TV talk shows including the personality of the host and his/her interviewees, the topic of interaction and the way through which a character deals with a certain topic.
\end{abstract}

Keywords: humor, functions, interpersonal interaction, topic shift, TV talk shows

\section{Humor}

\subsection{An introduction}

It is difficult to define humor because it is a broad term that fits with many of what people say or do. The term humor is considered a synonym to parody, irony and comic. This proves that humor is perceived as something funny that makes others laugh (Rufaida, 2017, p. 7). The word humor is derived originally from the Latin word "humorn" which means "liquid" or "fluid". It still retains this meaning in psychology in reference to bodily fluids such as the "aqueous and vitreous humorous of the eye" (Martin, 2007, p. 20). In English, the word "humor" is derived from the French word "humur" in the 16th century. Humor "is an unbalanced temperament or personality trait led to refer to any behavior that deviates from social norms"(Ben Jonson, 1998). Midness (1971, p. 21), on the other hand, defines humor as "a frame of mind, a manner of perceiving and experiencing life, it is a kind of outlook, a special point of view and one which has a great therapeutic power". Scholars believe that humor is connected to laughter and they often deal with them together. When people perceive something as humorous, they tend to laugh. Though laughter is one type of prototypical response to humor, laughter is not always equal to humor because laughter can have other meanings. Sometimes, it expresses aggressiveness, nervousness and embarrassment. In addition, people laugh when they are tickled (Hucheson, 1994, p. 61). In this regard Morrison (2012), as cited in Ibraheem and Abbas (2016b), states that people who appreciate humor and humorists are described as having 'a good sense of humor'; the ability to respond to humorous situations either by laughing or smiling.

Barbara Plester (2016, p. 5) says that "humor, fun and laughter are commonly confounded" Though so many scholars have tried to define humor and differentiate it from laughter, their definitions have neglected the dark side of humor. Humor can be funny for some people still it can be "offending and upsetting to others" (Ibid). From all the above mentioned definitions it is "evident that humor is a broad term that refers to anything that people say or do that is perceived as funny and tends to make others laugh as well as the mental processes that go into both creating and perceiving such an amusing stimulus, and also the affective response involved in the enjoyment of it" (Martin, 2007, p. 5). 
Humor has been studied by many scholars and researchers to analyze literary discourse such as Trillo (1997), Galinanes (2000), Okado (2001), and Ermida (2002). Series have also been pragmatically studied by using humor such as Allen's study (2003), Xiaosu's (2009), Alvaro's (2011), Savkanicova's (2013), Dynel's (2013). This study is intended to examine the use of humor in TV Talk Shows, namely, Oprah Winfrey Show and Piers Morgan Show using the incongruity theory and the relief theory.

\subsection{Humor Factors}

Few people are characterized as having sense of humor who may be socially popular if their society thinks of humor in high esteem. Humorous people have humor competence that differentiates them from those who do not Humorous people have the ability to respond to funny stimuli more easily. Raskin $(1985$, p. 3$)$ believes that there are many factors for humor to be performed adequately. He calls "an individual occurrence of a funny stimulus a humor act". This act is characterized by the following factors:

1) Human participation: for any humor act to be adequate, there should be human participants. The participants may include the speaker and one or more hearers. The speaker may be replaced by "the writer, radio, television or any substitute speaker" while the hearer may be substituted by "the readers, the radio or television audiences" (Raskin, 1985, p. 4). The physical presence of a human participant is a necessary factor for the humor act to be fulfilled. This sole participant is usually the hearer, the perceiver and the addressee of the humor stimulus.

2) The stimulus: a new stimulus should be presented and responded to humorously. This stimulus is an utterance, a situation that has to be perceived.

3) The life experience of an individual: what makes a person laugh at a certain time may fail to make him laugh twenty years or so after.

4) The psychological type of an individual participating in the humor act: this factor with the experience of the individual determines the degree of the predisposition to humor in a given situation.

5) The situational context: Raskin $(1985$, p. 5) believes that "every humor act occurs in a certain physical environment which serves as one of the most important contextual factors of the humor act".

6) The society: humor act occurs within a certain culture. This culture belongs to a certain society which has certain social values and norms. Many researchers have commented on this fact and the way it affects the interpretation of the humor act (Raskin,1985, p. 5).

\subsection{Functions of Humor}

Humor has a variety of functions in interpersonal interaction. These functions prove that humor is a strategic means of communication that is used to achieve certain conversational goals. Humor can function as a means that is used to facilitate communication, develop interpersonal relationships, exert power and social control, transmit verbally aggressive messages and to express excitement or joy (Elizabeth, 1992, pp. 165-167). Moreover, she concludes that humor serves a strategic function to the extent that the use of humor accomplishes an individual's interactive goal. Since humor serves a variety of functions in interaction, the researcher of this study intends to show the functions of humor in TV talk shows and how it can sometimes be used to shift the topic of interaction in the course of conversation.

\subsection{Forms of Humor}

Different forms of humor are communicated by different means for different purposes. Some of this humor comes from the mass media such as radio's witty comments. Besides, TV. provides us with humor in the form of sections, blooper shows, standup comedy, political and humorous advertisements. Newspapers as well as comic scripts and cartoons can provide humor. These forms can be presented either as "verbal humor" or "non-verbal humor". The forth mode is done through language while the latter is done through nonverbal acts like cartoons, gags, ...etc. and it depends on visual stimulus rather than verbal. The present study deals with verbal humor, as such nonverbal humor is beyond the scope of it.

\subsubsection{Verbal Humor}

The following are the categories of verbal humor:

1) Deliberate ridicule: This is done by making fun of somebody or something (Raskin, 1985).

2) Malapropism: This type of humor takes its name from the comedian character Malaprop who is a character in Sheridan's play “The Rivals". This character does not utter any word in the right way. Instead, he uses one of the similar sounds but in an inappropriate way. Thus, the result is producing humorous utterances (Ross, 1998, p. $11)$. 
3) Spoonerism: This type of humor is named after Reverend William Archibald Spooner a famous Oxford professor who is known for his transposition of the sounds of two or more words resulting in the production of funny utterances (Ibid).

4) Allusion: It is "the extra-linguist knowledge about the world. The double meaning may involve references to saying or quotation" (ibid). If the listener does not have a common background with the speaker, ambiguity is not recognized.

5) Satire: It is a way to make sync between criticizing, foolishness, and or stupidity through ridicule with the aim of altering and making reform.

6) Parody: It is a humorous imitation of style (Ibid, p. 47).

7) Irony: It expresses the meaning, often humorous or sarcastic, but through "the use of language of a different or opposite tendency" (Ibid, p. 50).

8) Lapses: It is an unintentional humor such as a slip of the tongue.

\subsection{Theories of Humor}

Humor has been given considerable attention by scholars from different fields. Many theories and approaches have appeared. Three of the most prominent theories to humor are: the incongruity theory, the superiority theory and relief theory (Ibraheem \& Abbas, 2016a). Contemporary humor scholars seem to agree that these three major theories of humor are not exclusive to each other, they are mentally connected and share the same concepts.

\section{1) Incongruity Theory}

Kant (1724-1804) was the first author who was generally associated with the Incongruity Theory of humor. This theory pays attention to the "suddenness of the transformation and to the fact that the expectation is turned into nothing" (Attardo, 1994, p. 48). Therefore, this theory is based on the mismatch between two ideas. Moreover, this theory refers to something which is not in its appropriate situation. It must be enjoyed so that it will be considered as humor (Ruch, 2008, as cited by Marfo, 2015). It is this theory that is mostly appropriate to the analysis of the present study. According to the congruity theory, Boss (2012) and Purzycki (2011) state that humor comes from one situation or idea having multiple meanings or senses. In this sense, Boss (2012, p. 241) concludes that "in order to be humorous, an entity would need to have more than one possible interpretation, or, in other words, to represent a certain degree of ambiguity. Subsequently, we can assume that this ambiguity is the factor that 'deceives' humor recipients, misleads them and finally surprises by 'disambiguation' and revealing the proper solution of the situation".

\section{2) Superiority Theory}

This theory indicates that "laughter arises from a sense of superiority of the laugher towards some objects" (Attardo,1994, p. 48). Thus, it expresses the negative side of humor which is the aggressive one. It is based on hostility, malice, aggression, derision, or disparagement. Hobbes considers the passion of laughter "nothing else but a sudden glory arising from some sudden conception of some eminency in ourselves, by comparison with the infirmity of others and with our own" (Hobbes as cited in Kashin, 1985, p. 36). Humans normally laugh because of a 'sudden glory'. The 'sudden glory' is caused either by the anxiety of some deformed thing in others, or by some surprised act of their own. This type of humor is generated from simple naïve thoughts and misadventures of young people or children who can represent a very important source of amusement. Superiority can include superiority over the person's own former position, and not just aimed at others (Cross, 2011, p. 9).

\section{3) Relief Theory}

It was first proposed by Spencer and Freud. It is based on the assumption that laughter can be described as something like a safety valve to release anxiety and tension (Gruber, 2008, p. 37). Mindess (1971, p. 31) believes that "our sense of humor frees us from the chain of our perceptual, conversational, logical, linguistic, and moral systems" He regards humor as a liberation from what we are trying to escape. Besides, Moreal (1983) argues that the relief theory may not be a separate theory from the superiority and incongruity theories, but rather a complement theory that looks at different aspects (as cited in Andrew \& Anderson, 2007, p. 6). As such, it is this theory that will be applied in the analysis of the episodes because it is the most related to achieve the objectives of the present study.

\subsection{Grice's Conversational Implicature}

In a normal conversation, both parties, the speaker and the hearer, communicate according to a set of rules they 
usually obey. Grice (1975) established a set of four maxims called 'conversational maxims' that should be followed to ensure a smooth interaction. Typically, speakers do not observe all such maxims the whole time. Usually, one or two of them are observed in every day conversation. In other words, these maxims may be perfectly observed if and only if speakers obey their rules. When speakers intentionally fail to observe a maxim, to make a specific point or to express a non-literal meaning, a conversational implicature is generated. This means that speakers violate such maxims to some extent on the surface of the talk but they commit to them at some deeper level of communication.

\section{Topic}

Topic is defined by Coates (1996, p. 68) as a "chunk of talk that hangs together because it is about the same thing". It is the subject of interaction over which conversation evolves and is developed by the participants in the conversation. As such, participants are likely to produce relevant talk that is connected to one another's talk. The hearer, for example, produces an utterance that is related to what the previous speaker has produced. As such, participants should speak topically and be cooperative (James, 1995, p. 33). Moreover, most topics of interaction are not fixed previously. Instead, they are negotiated and developed by participants in the process of conversation.

\subsection{Topic Shifting}

Wordhaugh (1971) argued that a conversation usually covers a number of topics and involved shifts from one topic to another. It means that in a conversation, the speakers do not only talk about one topic from the beginning to the end, they tend to shift from one topic to another. These topics that emerge within the main one can be considered as sub - topics of the previous topic or a new topic. Similarly, topic shift is the change of a topic in a conversation when the speakers talk about another subject and discuss it in the course of conversation to make it more interesting and effective.

\subsection{Talk Show Genre}

Talk show is a modern "Anglo-Saxson" institution. It has emerged in the early $1930_{\text {s }}$ when radio talk shows appeared in the United States. The talk show is a sort of socio-cultural practice of purposeful talk (Ilie, 2006). Later on, TV talk shows have appeared. They provide both talk as well as entertainment (Signes, 2000).

The talk show displays "a hybrid broadcast discourse". It employs conversational as well as institutional discourse. As such, some scholars call this genre "semi-institutional". It is semi-institutional since some forms of natural conversation are 'embedded' within its institutional aspect (Ilie, 2001, pp. 489-490).

Though this genre is "highly planned" and it is 'anchored' by a host (or a group of hosts), Timberg (2002, p. 3) believes that "no matter how planned or formatted", the talk show is based on what is called "fresh talk" i.e., spontaneous. He believes that a TV show is "entirely structured around the act of conversation".

\subsection{Topic Shift and Humor}

Humor is a multifunctional aspect of language and it is very useful in our life. If somebody wants to change someone's mind, he needs just to mix seriousness with humor and it will give him a good result. Moreover, when a person does not want to talk about a certain topic, he can avoid it by producing a humorous utterance thus giving the other participant a clue that he is not ready to talk about this topic. Thus, humor can be used as a topic shifting strategy.

\section{Methodology}

The present study is qualitative in nature. It examines the extracts in their contexts. Moreover, it aims at giving a thorough analysis of the extracts by examining them, picking up the humor act and presenting its type and function. The incongruity theory of Kant (1790) and the relief theory of Moreal (1983) constitute the theoretical framework on which the researcher will depend. Two talk shows have been selected for the analysis, namely, Oprah Winfrey Show and Piers Morgan Show. Two episodes are chosen from each show. Four extracts are selected from each episode to be analysed. Then, a comparison is conducted so as to tell which host uses humor more than the other and what functions and types are used and why.

\section{Data Analysis}

This section is dedicated to the analysis of the selected extracts from two TV Talk shows which are Oprah Winfrey Show and Piers Morgan Show. Two episodes are selected from each show. From each episode, four extracts are selected. These extracts are contextualized and analyzed in an elaborated manner to examine the different types and functions of humor in TV Talk shows. This examination is based on certain steps: identifying 
exactly where humor lies in the utterance, by which character and then specifying the type of humor produced by the character.

\section{The Two TV Talk Shows}

Two TV talk shows will be presented and analyzed namely Oprah Winfrey Show and Piers Morgan Show.

\subsection{Oprah Winfrey Show}

Oprah Show is one of the most popular TV talk shows around the world. Oprah Winfrey is the host of the show. She tackles different topics and issues with her interviewees. She is considered as the most influential TV show host. From this show, two episodes are selected: Will Smith and family interview and Donald Trump interview.

\subsubsection{First episode: Will Smith an family interview}

In this episode, Oprah interviews the popular actor Will Smith and his family. She discusses with him many issues concerning his work, family and beliefs.

\section{Extract one:}

Oprah: what is the bigger vision for your marriage, what is the bigger-

Jada: well, we had to figure that out because we're two big beings that come together and I had my vision and he had his so we decided to

Will: just do what she says (laughter)

Jada: Yeah. basically. that's the vision

\section{Contextualizing the extract:}

Oprah is talking to the Smith's family asking them about the bigger vision of their marriage. Jada is the addressee who answers Oprah's question. In the meanwhile, Will interrupts Jada by producing a funny comment.

\section{Analyzing the extract:}

When Will interrupts Jada, by violating the maxim of relation, Oprah and the audience start laughing. This happens because Will's comment is a funny joke that raises humor. The function of humor in this extract is to evoke laughter by embedding humor within seriousness "Just do what she says". This humorous instance has disturbed Jada who is talking about the addressed subject in a passionate way, yet, the cooperative principle is still at work since she agrees by saying "Yeah, basically. That's the vision".

\section{Extract two}

Oprah: Okay, so we're going to break it. You talk about-he gets his treats. I want to know what you do to keep this flame burning.

Jada: Now, how saucy do you want to get Oprah (laughter)?

Oprah: well. I wouldn't mind hearing one or two.

\section{Contextualizing the extract}

Oprah is talking to Jada asking her about the way she keeps the flame of love burning between her and Will. Jada asks Oprah how far she wants to know about this matter. The audience laugh because it is a personal issue.

\section{Analyzing the extract:}

Since Oprah asks about a very personal issue, Jada gives her a hint about "how saucy" she wants to get about this subject. This hint can be related to violating the maxims of manner by not being straight and maxim of quantity by saying more than is required which in turn raises laughter and embarrassment at the same time. Oprah gets Jada's point and tells her that she wouldn't mind hearing one or two. Humor here is caused by the subject of interaction and the expected answer which is a private one. The type of humor here is the witty answer Jada produces.

\section{Extract three:}

Oprah: I am not giving too much a way when I say that you had your first onscreen kiss

Jayden: yeah, I had my first onscreen kiss. Yeah (laughter)

Oprah: and was this challenging for you?

Jayden: um I mean I'm good at kissing so-(laughter)—so it wasn't as challenging as it could've been

Oprah: it wasn't as challenging as it could've been, had you not had some previous experience! 
Jayden: yeah, uha (laughter)

\section{Contextualizing the extract:}

Oprah is talking to Jayden about his film "The Karate Kid". She tells him that she is not exaggerating when she says that he has his first onscreen kiss. Jayden agrees with her proudly. The audience laugh.

\section{Analyzing the extract:}

Jayden's answer to Oprah's question is not expected to be in this way. Therefore, Oprah and the audience start laughing. There is an incongruity between Oprah's question and the given answer. Oprah and the audience are surprised with Jayden's answer so they laugh. The type of this humor act is parody, Jayden tries to act like adults but in a funny way. The function of humor in this example is to show surprise.

\section{Extract four:}

Oprah: so, do you think your parents are cool or do they sometimes embarrass you Jayden?

Jayden: hum, my parents embarrass me all the time.

(laughter)

Oprah: they do! I didn't expect that answer.

\section{Contextualizing the extract}

Oprah is asking Jayden about his parents if they are cool or they cause embarrassment. Oprah and the audience laugh because his answer comes contrary to their expectation.

\section{Analyzing the extract}

The audience and Oprah laugh at Jayden's answer. They have not expected such an answer. Thus, there is a mismatch between Oprah's and the audience's expectation of what the answer is to be and between Jayden's unexpected answer. Humor here is used to express astonishment. Jayden's answer violates the maxim of quantity because he gives more than is required by stating 'all the time' to cause laughter.

\subsubsection{Second Episode: Donald Trump and Family Interview}

In this episode, Oprah interviews Donald Trump and his wife. Then, she interviews the other members of the family asking them about different topics concerning their family.

\section{Extract one:}

Oprah: did they all like you immediately?

Melania: well, I don't know. Did they? (laughter)

Donald: ... they really loved Melania.

Oprah: why? We'll ask them. (laughter)

\section{Contextualizing the extract:}

Oprah asks Melania if the Trump's children liked her immediately. Melania expresses her lack of certainty concerning this matter. Then, she addresses a question to Donald asking him whether his children liked her immediately.

\section{Analyzing the extract:}

Melania answers Oprah's question with irony expressing her uncertainty through the use of 'well' followed by 'I don't know'. This irony causes the audience to laugh. Thus, it is perceived by the audience as something funny. This humorous act functions as a means that expresses Melania's lack of an adequate answer to Oprah's question.

\section{Extract two:}

Donald: ... I ran a lot of hotels you know. A lot of hotels. I screamed at people why you are late. But now I understand I'll never scream again.

Oprah: really! (laughter)

Donald: never-yeah may be not. One may be a little bit.

\section{Contextualizing the extract:}


Donald tells Oprah that though he has a lot of hotels, he does not know how difficult the job of his employees is in these hotels. But now he understands them and he will never scream at them again. However, Oprah expresses her doubtfulness and the audience laugh. Donald reformulates his utterance saying that maybe he will scream a little bit.

\section{Analyzing the extract:}

Oprah's question 'Really?' about Donald's ability to fulfill his promise is ironic. It expresses Oprah's doubtfulness concerning Donald's words. The audience laugh at this question since they perceived Oprah's clue. The function of this humor act is to express doubtfulness. The effect of this function makes Donald violate the maxim of manner as he becomes ambiguous in his last utterance especially when he expresses his negative answer in three levels of doubtfulness 'never', 'yeah may be not' and 'One may be a little bit'.

\section{Extract three:}

Oprah: ... did you give Ivanka a budget for that?

Donald: well, she had a budget. It was unlimited and she exceeded it.

(laughter)

\section{Contextualizing the extract:}

Oprah asks Donald if he has given his daughter Ivanka a budget for her marriage. He tells Oprah that he gave his daughter an unlimited budget; however, she exceeded it. Oprah and the audience laugh.

\section{Analyzing the extract:}

Donald's answer to Oprah is ironic. He says that though he gave his daughter an unlimited budget, she exceeded it. This humor act is used to function as an indirect message by Donald to his daughter. Maybe he could not tell her before about this matter. So, he exploits this chance to send his message to Ivanka. This indirectness is expressed by the violation of the maxim of manner by being unclear or vague.

\section{Extract four}

Melania: yes, of course and we have a great relationship. You know, they are a little bit younger than me and eh

Oprah: good! (laughter)

Donald: not much (laughter)

\section{Contextualizing the extract:}

Oprah asks Melania about her relationship with Trumps kids. She tells her that she has a great relationship with them. She adds that they are a little bit younger than her.

\section{Analysing the extract}

Oprah's reply to Melania is ironic. She says "good" in an ironic way to express her surprise because Melania is exaggerating by saying that the kids are a bit younger than her. Donald's "not much" is uttered with laughter to lessen Oprah's surprise which is already said with laughter.

\subsection{Piers Morgan Tonight Show}

\subsubsection{First Episode: Ricky Gervais's Interview}

In this episode, Piers interviews Ricky Gervais, one of Hollywood's comedy stars.

\section{Extract one:}

Gervais: So I don't apologize for people not getting it. If anyone gets it, it's gettable. And there's always-as I said, there's always going to be someone that's offended by what you say. Many people are offended because you exist, particularly-you. Now I-(laughter)

Gervais: Again, I've read the forums. But what are we meant to do?

\section{Contextualising the extract}

Gervais is talking to Morgan telling him that he is a comedian and his aim is to make people laugh. So, he would not apologise for people who would not get the point because the people who laugh at his jokes get that he is joking. That means his jokes are gettable. Then, he tells Morgan that "there is always going to be someone that is offended by what you say". It is hard to satisfy all people. He jokes with Morgan telling him that there are people who are offended by his existence. 


\section{Analysing the extract}

Gervais is talking about the goal of his job as a comedian. He is sure that he cannot satisfy all people. He tells a joke that carries behind it an ironical fact. Some people are even offended by your existence, so you can not satisfy them all. The aim of this joke is to show satire.

\section{Extract two}

Morgan: You've had this amazing career path, amazing, in many ways. If I was to have the power to relieve for you one moment - this is not personal. It would be professional, really — a moment in your life, what would it be?

Gervais: There's loads of things whizzing through my head, but they're all from childhood.

Morgan: Like what?

Gervais: I just remembered one. My brothers and sisters are a lot older than me by-the next one is 11 years old, then 13, then 15. And I remember I was 12. I was eating my Corn Flakes.

And I said to my mom, I said, mom, why are all my brothers and sisters so much older than me?

She went on, because you were a mistake (lasughter).

Gervais: I just laughed. I went cheers. I love honesty of growing up. There's a little thing like that that I sometimes just-

\section{Contextualising the extract}

Morgan asks Gervais about a moment from his life that would be of relief to him. Gervais tells him that there are many things in his head and they are all from his childhood. Morgan asks him "like what?" Gervais tells him that he remembers one day when he asked his mother why his brothers and sisters are much older than him. She answered him that it was because he was a mistake.

\section{Analysing the extract}

The instance that Gervais mentions is humorous. It makes both Gervais and Morgan laugh. However, it is ironic because the hidden meaning of it is that Gervais was not considered as a blessing to his parents, instead he was a mistake. Gervais violates the maxim of quantity by saying more than is required "There's loads of things whizzing through my head" followed by "but they're all from childhood" to prepare Morgan for the laughter which functions as an amusement.

\section{Extract three:}

Morgan: And you've been with the same woman 30 years.

Gervais: Yes.

Morgan: She's a lovely, smart, attractive-

Gervais: Here we go.

Morgan:-long-suffering woman.

Gervais: Yes. Yes.

Morgan: Why haven't you married her yet?

Gervais: Well, we are, really. We are.

Morgan: And yet you're not.

Gervais: Well, I mean we've-we've-you know, we share everything.

Morgan: Do you think you ever will?

Gervais: Oh, I'd never say never. There's no reason we're not getting married other than there's no point at the moment. There might be one day, but it's not-it's not a-I'm not digging my heels in going, we can never get married for any reason. We just-there's-there's no point.

You know, we don't want our families to meet. That's the thing.

(laughter)

\section{Contextualising the extract}

Morgan asks Gervais why he has not got married to his girlfriend though he has been with her for thirty years. He tells him that they are married by the bond of love. Morgan says "yet you aren't". Then, Morgan asks him 
"do you think you ever will?" Gervais answers him that he can not say that he would never. He tells him that there is no reason to get married. Then, he says that they want their families to meet. That is the thing.

\section{Analysing the extract}

Though Gervais is talking about a serious matter, he manages to use humour to end the topic in a humorous way. To do so, the maxim of quantity is violated by stating more than is required. He gives a witty response that is humorous so as to end the topic and shift it to another.

\section{Extract four}

Morgan: Do you like Steve Carel

Gervais: He's great. He's fantastic. He's not only brilliant, but he's one of the loveliest people in Hollywood - untouched by it, family man, nice, honest. Yes, I've got nothing but good to say about him.

Morgan: He's got-as I said to him, he's got one of-it's a great interview and we're going to run it very soon. But he's got one of those heads that's just funny.

Gervais: He's good, because you know why?

He's got-he's nearly handsome. (laughter)

Gervais: He's got that-he's-he's got-(laughter)

Gervais: - he's-he's like Bob Hope. If you look at him, he's chiseled, he's great. But he's got something-he's got beady eyes. He's good. I like him. I like-And that was a compliment, by the way.

\section{Contextualising the extract}

Morgan asks Gervais about Steve Carell. Gervais starts complimenting him. He praises his appearance. He says that he is good because he is handsome. He describes him as being like Bob Hope in that he has got beady eyes. Then, he tells Morgan that what he says is a compliment in order not to be misunderstood.

\section{Analysing the extract}

Gervais uses humour more than one time in this extract. In the first place, he talks about how Steve Carell looks and how handsome he is. This makes the audience laugh. This is due to violating the maxim of quality. Then, he continues talking about the appearance of Steve Carell and about the ceature he likes in him "he's got beady eyes". He tells Morgan that when he talks about Steve Carell in this way, he is complimenting him. The audience laugh at his talk. His aim is to show that his intention is not to make fun or belittle Steve Carell.

\subsubsection{Second Episode: Morgan's interview with Winfrey}

In this episode, Piers Morgan interviews Oprah Winfrey. He asks her many questions concerning her life, love and work.

\section{Extract one}

Morgan: What advice would you give Michael Vick?

Winfrey: What advice? You know, I don't want to talk about Michael Vick because I am trying to interview him.

Morgan: Really? (laughter)

I love that honesty about you.

Winfrey: So, I will just save all my advice for when I sit down with him. I know you are trying to interview him.

Morgan: I'm trying to get him as well. One of us is going to win.

Winfrey: One of us is.

Morgan: Do you want wager? (laughter)

Winfrey: No.

\section{Contextualising the extract}

Morgan asks Oprah about the advice she would give to Michael Vick. She tells him that she plans to interview him, so she will save it for that time. She tells him that she knows he is trying to interview him as well. He tells him that one of them will win. Then he asks her if she wants to make a bet. Oprah laughs and says no.

\section{Analysing the extract}


When Oprah tells Morgan that she intends to interview Michael Vick, he laughs and says that he loves her honesty. He laughs since he gets Oprah's hint that she is trying to interview him first. They say that one of them will win. Morgan jokes with Oprah asking her if she wants a wager. Oprah laughs and says no. Here humor works to amuse the audience who patiently waits for a comment from the two celebrities.

\section{Extract two}

Morgan: I got that this person was your great friend but your gate keeper. I had to persuade Gayle that I was trustworthy.

Winfrey: I think that's very smart of you to go through Gayle to get it.

Morgan: Sneaky actually. (laughter)

But I had to get Gayle.

\section{Contextualising the extract}

Morgan tells Oprah that he got to know Gayle in the last couple of months when he was trying to convince Oprah to have an interview with him. He tells her that he finds hilarious and very protective towards Oprah. So, he had to persuade Gayle that he is trustworthy. Oprah tells him that she thinks it very smart of him to do that. He jokes with her saying "sneak actually". They laughed.

\section{Analysing the extract}

After Oprah praises Morgan for his smartness, he jokes with her telling her that his way of getting Gayle was a sneaky one but still he has to do that to get her.

\section{Extract three}

Morgan: That's real love. I love every Australian passionately because we destroyed them at the sport they love most.

Winfrey: I'm not talking about that kind. (laughter)

Morgan: You don't like cricket?

Winfrey: Cricket is fine. But I'm talking about, you know-

\section{Contextualising the extract}

Oprah tells Morgan about her experience in Australia and how lovely it was. However, Morgan talks about his huge love towards Australia since they have beaten them in cricket. Oprah tells him that his is a different kind of love. Though, he tells her that it is a real love, Oprah says that she is not talking about this kind. Morgan laughs and asks her indirectly if she does not like cricket. She tells him that cricket is fine, but the kind of love he is talking about is not.

\section{Analysing the extract}

Morgan tries to be funny and humorous, however he fails to do so because Oprah does not respond to his talk in the way he expects. She feels that this humor is not good. It aims at making fun of other people and she does not like to do so. Therefore, the humorous act Morgan uses here has failed to achieve its aim since she does not agree with him. This also can be seen as vagueness on the part of Morgan since he intends to violate the maxim of manner by not answering the question "You don't like cricket?" with yes or no. This comes as a result of the laughter that accompanies Oprah's "I'm not talking about that kind".

\section{Extract four}

Morgan: Do you still read them?

Winfrey: No, I haven't read them in years. They're in a safety deposit box somewhere.

Morgan: Wow, that's amazing.

Winfrey: I was thinking I should burn them now because Gayle knows if anything happens to me, get the letters.

Morgan: I have a message for Gayle, give me the letters. (laughter)

Winfrey: Get the letters and journals.

\section{Contextualising the extract}

Oprah is telling Morgan about the letters she has from her previous relationships. He asks her if she has them all. She says yes. He asks her if she is still reading them. She tells him that she does not know why she kept them 
and she has not read them in years and they are in a safe place. She tells Morgan that she thinks that she should burn them now. Morgan jokes with Oprah and tells her that he is having a message for Gayle and both laugh.

\section{Analysing the extract}

Morgan jokes with Oprah by asking Gayle to give him Oprah's messages from her previous relationships. His aim to here is to facilitate the interpersonal communication and to make their conversation enjoyable. Besides, it is intended to strengthen the relationship between him and Oprah and to amuse the audience. Because of this reason, he violates the maxim of relation when he tells Winfrey "I have a message for Gayle".

\section{Comparing Humour in the Two TV Talk Shows}

Humour in TV talk shows seems to be dependent on the personality of the host of the show. He or she is the one who gives his interviewees the chance to show their sense of humor depending on the topic the host initiates and the way questions are formulated. Moreover, the interviewees' character gives the host the opportunity to evoke humor through their interaction.

In this paper, two TV shows have been analyzed. One is hosted by Oprah Winfrey and the other by Piers Morgan. From each show, two episodes have been selected. In the first selected episode from the Oprah Winfrey show, Oprah interviews Will smith and family. They are all actors and they have sense of humor. This is obvious through their conversation with Oprah. Will's funny comment, Jada's witty answer and Jayden's openness are the factors that have made the interaction in this episode as humorous and as funny as it was. In the second episode of Oprah Show, Oprah interviews Donald Trump and family. Donald Trump is a politician. However, he has a good sense of humor. He produces many ironic and humorous utterances. In this episode, Melania's uncertainty and her exaggerating replies raise humor and laughter.

In addition, two other selected episodes from Piers Morgan show have been analyzed. In the first one, Morgan interviews Ricky Gervais who is one of Hollywood's comedy stars. Gervais is a comedian whose job is to make people laugh by using his sense of humor. He is a witty person. He produces utterances that raise humor but they are ironic and embody bitter reality. In the second episode, Morgan interviews Oprah Winfrey. She is the most popular TV talk show host in the world. She is a witty person who knows how to deal with people and she has a sense of humor. This is obvious through her interaction with Piers.

As for the show hosts personality, Oprah seems to be more intimate, friendly and natural with her interviewees. This gives her advantage to ask what she wants in the way she wants to get the required answers. Piers, on the other hand, appears to be more artificial and tries to be humorous but sometimes he fails.

When it comes to Grice's maxims and according to the analysis of the extracts, the most non-observed mechanism is that of violation. It is most evident when the characters tend to violate the maxim of relation to shift the topic of interaction and create humor. The maxim of quantity is also violated so as to raise humor and laughter.

\section{Conclusion}

Humor as an act of interpersonal interaction has many purposes such as teasing somebody, humiliating somebody, breaking the tension from tough situations, or simply making fun. Yet, after conducting this study, the researcher has come to the conclusion that humor, in relation to the violation of Grice's maxims as well, can also be used to achieve many interpersonal aims in interaction such as ending a topic, shifting to another topic, embedding bitter reality within humorous utterances and expressing inner ideas and feelings that may hurt if produced in a serious way. Moreover, there are many factors that affect humor in TV talk show. These are the personality of the host and his/her interviewees, the topic of interaction and the way each character deals with a certain topic.

\section{Acknowledgements}

The researcher of the present paper is grateful to the College of Education for Women, University of Baghdad, Al-Jadiriyya, for conducting this research paper.

\section{References}

Andrew, M., \& Anderson, P. (2007). A theory of rhetorical humor in political discourse. California: ProQuest.

Attardo, S. (1994). Linguistic theories of humor. Hawthorne, NY: Mouton de Gruyter.

Boss, T. (Ed.) (2012). Agents and ambient intelligence: Achievements and challenges in the intersection of agent technology and ambient intelligence. Washington: IOS Press

Coates, J. (1996) Women Talk. Oxford and Massachusetts: Blackwell. 
Cross, J. (2011). Humor in contemporary junior literature. London: Routledge.

Elizabeth, E. G., Michael, J. P., \& Gordon, P. B. (1992). Functions of humor in conversation: Conceptualization and measurement. Western Journal of Communication, 56(2), 161-183. https://doi.org/10.1080/10570319209374409

Gregori-Signes, C. (2000). The tabloid talkshow as a quasi-conversational type of face-to-face interaction. Pragmatics, 10(2), 195-213. https://doi.org/10.1075/prag.10.2.02gre

Grice, H. P. (1975). Logic and Conversation. London. Elsevier.

Gruber, E. (2008). Humor in contemporary native north American literature. New York: Camden House.

Ibrahim, S. D., \& Abbas, N. F. (2016a). A Pragmatic Study of Humor. Journal of Advances in Language and Literary Studies, 7(1), 80-87.

Ibrahim, S. D., \& Abbas, N. F. (2016b). Pun and (UN)intentional humor. Journal of American Academic Research. JAAR publishing center. San Francisco, CA, USA.

Ilie, C. (2001). Semi-institutional discourse: The case of talk shows. Journal of Pragmatics, 33(2), 209-254. https://doi.org/10.1016/S0378-2166(99)00133-2

Ilie, C. (2006). Talk Shows (pp. 489-493). Örebro University. Örbro, Sweden: Elsevier Ltd.

James, A. D. (1995) Topic Shift in Casual Conversation, Totem. University of Western Ontario Journal of Anthropology, 2(1), 8.

Marfo, C. O. (2015). Pragmatics of Humor at the Workplace: A Case study. University of science and technology.

Martin, R. A. (2007). The Psychology of Humor: An Integrative Approach. California: Academic Press. https://doi.org/10.1016/B978-012372564-6/50024-1

Mindess, H. (1971). Laughter and liberation. Los Angeles: Nash Publishing.

Moreal, J. (1983). Talking laughter seriously. New York. Sunny Press.

Morrison, M. K. (2012). Using Humor to Maximize Living: Connecting with Humor (2nd ed.). Plymouth: R \& L Education.

Pusrzycki, B. (2011). Humor as violation and deprecation: A cognitive anthropological account. Journal of Cognition and Culture, 11(1), 217-230. https://doi.org/10.1163/156853711X568752

Raskin, V. (1985). Semantic mechanisms of humor. Dordrecht: D. Reidel.

Ross, A. (1998). The language of humour. Routledge: London.

Timberg, B. M. (2002). Television talk: A history of the TV talk show. Austin: University of Texas Press.

\section{Copyrights}

Copyright for this article is retained by the author, with first publication rights granted to the journal.

This is an open-access article distributed under the terms and conditions of the Creative Commons Attribution license (http://creativecommons.org/licenses/by/4.0/). 